\title{
Pemberdayaan Anak Didik Pemasyarakatan Melalui Bamboo Batik Speaker
}

\section{Rima Sumiar Achrima1, Reni Eka Septianingrum², Rokhmatun Hanifah ${ }^{3}$, Erina Rahayu $^{4}$,Syaifullah Filard Latifan ${ }^{5}$, Muhammad Rustamaji ${ }^{6}$}

\author{
1, 2, 3, 4, 5, 6 Universitas Sebelas Maret \\ ${ }^{1}$ rimasumiar@gmail.com, ${ }^{2}$ reniekaseptianingrum@gmail.com, \\ 3hanifahrohmatun08@gmail.com, ${ }^{4}$ erinarahayu8@gmail.com, \\ 5ifan.sfl7@studentt.uns.ac.id, ${ }^{6}$ hatchi_ajie@yahoo.com
}

\begin{abstract}
Abstrak
Lembaga Pembinaan Khusus Anak (LPKA) seharusnya bukan hanya dianggap sebagai jurang nestapa, namun juga sebagai lokus penyalur aspirasi dan kreativitas bagi Anak Didik Pemasyarakatan (Andikpas), karena sejatinya setiap anak mempunyai potensi diri. Alasan demikian yang mendasari dirumuskannya progam pembinaan kemandirian berbasis keterampilan yang memegang peran penting dalam mengembangkan dan mempersiapkan Andikpas untuk mempunyai kesempatan baru sekeluarnya dari LPKA. Namun, senyatanya progam pembinaan kemandirian di LPKA Yogyakarta kurang berjalan dengan baik dikarenakan keterbatasan dana dan sumber daya manusia yang memadai. Oleh karena itu perlu diadakan penjalinan kerjasama dengan mitra guna menjawab permasalahan yang dihadapi. Melihat potensi dan minat Andikpas dalam hal seni dan elektro, maka dipilihlah progam berbasis produk Bamboo Batik Speaker (Booster). Pelaksanaan progam diawali dengan sosialisasi, pemberian materi dalam kelas, branding hingga marketing. Metode pelaksanaan yang digunakan pada kegiatan pengabdian ini adalah Participatoty Rural Appraisal (PRA). PRA merupakan suatu metode pendekatan dalam proses pemberdayaan dan peningkatan partisipasi komunitas sasaran yang penekanannya difokuskan pada keterlibatan komunitas sasaran dalam keseluruhan kegiatan progam. Hasil dari pemberdayaan ini adalah meningkatnya pengetahuan dan wawasan Andikpas dalam membuat suatu produk yang kreatif dan berdaya jual tinggi serta tumbuhnya jiwa enterpreneurship Andikpas. Adanya progam Booster juga berpotensi menciptakan income generating bagi Andikpas.
\end{abstract}

Kata kunci: andikpas, booster, pemberdayaan

\section{PENDAHULUAN}

Penjara, adalah sebuah tempat dengan bahasa, kepemimpinan, peraturan-peraturan, tata cara, dan ritual yang terdapat di dalamnya. Hal tersebut menjadikan penjara merupakan sebuah 'mikroskopis sosisal' (social microcosm) yang dianggap sebagai sebuah antitesis kehidupan yang memerlukan perjuangan lebih bagi para penghuninya (Gayatri et. al, 2016). Demi menyambung asa mereka harus menghadapi pergolakan dan pergulatan batin atas pembatasan kemerdekaan yang dimiliki. Seorang anak yang terbukti melakukan sebuah delik (tindak pidana) disebut Anak yang Berkonflik dengan Hukum (ABH) yang menjadikannya ditempatkan pada Lembaga Pembinaan Khusus Anak (LPKA) dengan sebutan Anak Didik Pemasyarakatan (Andikpas). Bagi seorang anak yang terjerumus dalam jurang nestapa penjara atas pertanggungjawaban atas perbuatannya tentu mempunyai tantangan lebih daripada 
selayaknya anak yang menjalani kehidupan yang wajar.

Secara psikologi, perkembangan jiwa dan mental anak yang berusia 12 hingga 18 tahun masih belum matang dan cenderung labil. Kejahatan yang dilakukan oleh anak didasari oleh delinquency (kenakalan anak) yang disebabkan oleh faktor intelegensia, faktor kepribadian, dan faktor dari masyarakat (Marlina, 2009). Pendekatan secara khusus yang menyebabkan delinquency dikarenakan penurunan mental (mental deficiency), gangguan berpikir (psychiatric disturbance) dan faktor dalam diri yang dimiliki seperti rasa malas, marah, tersinggung, dan sebagainya. Dengan demikian dapat disimpulkan bahwa delinquency utamanya disebabkan oleh pola individu dan perkembangan sang anak. Kepribadian anak sangat menentukan pola internal dalam diri anak, kemudian gangguan psikologi akan membentuk pola tingkah laku anak (Marlina, 2009). Selain itu pada peristiwaperistiwa yang bersifat kasuistik seperti menjadi korban kekerasan seksual, penganiayaan oleh orang tua, dan penelantaran anak oleh orang tua acapkali menjadi penyebab kekecewaan anak yang menjadi sumber anak untuk melampiaskannya dalam bentuk kejahatan. Kewajiban orang tua dalam memelihara dan menjaga anak dengan memastikan pemenuhan kebutuhan anak terpenuhi juga menjadi faktor penentu pembentukan karakter anak. Anak-anak yang tidak terpenuhi kebutuhannya, cenderung membentuk karakter yang memang tidak seharusnya dan tidak diharapkan dalam perkembangannya.

Mengingat jati diri anak yang masih belum terbentuk jiwa yang matang, menjadikan seorang $\mathrm{ABH}$ yang terbukti bersalah tidak akan mendapatkan hukuman atau pidana layaknya narapida di Lembaga Pemasyarakatan, melainkan akan mendapatkan pembinaan (Dewi et. al, 2014). Undang-Undang Nomor 12 Tahun 2012 tentang Sistem Peradilan Pidana Anak (UU SPPA) telah mewujudkan peradilan yang dapat menjamin perlindungan dan kepentingan anak. Pasal 86 UU SPPA telah mengatur bahwa anak yang ditempatkan di LPKA sudah sepatutnya berhak mendapatkan pembinaan, pembimbingan, pengawasan, pendampingan, pendidikan, dan pelatihan, serta hak lain sesuai dengan ketentuan peraturan perundang-undangan. Model pembinaan bagi narapidana dewasa dan anak (Andikpas) dilaksanakan berdasarkan Peraturan Pemerintah Nomor 31 Tahun 1999 tentang Pembinaan dan Pembimbingan Warga Binaan Pemasyarakatan. Progam pembinaan yang diberikan kepada Andikpas berbasis pendidikan. Tujuan dari pembinaan berbasis pendidikan tersebut dikarenakan sejatinya LPKA adalah sebuah tempat perbaikan diri bagi Andikpas untuk mempunyai kesempatan kedua melanjutkan kehidupan. Pembinaan tersebut bertujuan agar Andikpas memiliki kekuatan spiritual pengendalian diri, kepribadian, kecerdasan, akhlak mulia, serta keterampilan yang diperlukaan dirinya, yang akan berdampak baik sekeluarnya mereka dari LPKA. Umumnya, LPKA menyelenggarakan pendidikan non formal bagi Andikpas. Contoh pendidikan non-formal yang diberikan yaitu pendidikan kesetaraan (Paket A, Paket B dan Paket C), pendidikan keterampilan dan lainlain.

Pembinaan diberikan karena sejatinya anak pasti mempunyai potensi dalam dirinya, tak terkecuali dengan Andikpas. Setiap anak berhak memperoleh pendidikan dan pengajaran dalam rangka pengembangan pribadinya sesuai dengan minat, bakat dan tingkat kecerdasannya, tanpa adanya diskriminasi yang merupakan hak untuk tumbuh kembang, maka Andikpas pun perlu ruang dan sarana dalam mengembangkan bakat dan potensi dirinya sekalipun kemerdekaannya dibatasi. Pemberian pendidikan dan pelatihan keterampilan bagi Andikpas selaras pula dengan hasil Konvensi PBB pada pada Convention on the Rights of the Child (Konvensi Tentang Hak-Hak Anak). Konvensi tersebut mengatur bahwa perlindungan bagi anak atau remaja yang kehilangan kemerdekaannya berhak memperoleh : 1) Pendidikan; 2) Latihan keterampilan dan latihan kerja; 3) Rekreasi; 4) Memeluk agama; 5) Mendapatkan perawatan kesehatan; 6) Pemberitahuan tentang kesehatan; dan 7) Berhubungan dengan masyarakat luas. 
Selain itu, pembinaan pendidikan maupun pelatihan keterampilan tersebut bertujuan agar Andikpas mempunyai bekal untuk melanjutkan kehidupan sekeluarnya dari LPKA. Sekeluarnya dari LPKA mantan Andikpas tentu mempunyai tantangan yang berat dalam berintegrasi dengan masyarakat. Stereotip masyarakat yang menganggap mantan Andikpas sebagai anak nakal yang meresahkan serta catatan kriminalnya menjadikan mantan Andikpas kesulitan melanjutkan pendidikan maupun mencari pekerjaan. Stereotip masyarakat yang selalu memandang negatif terhadap Andikpas tersebut sudah barang tentu menjadi kultur. Padahal untuk mewujudkan tujuan pembinaan tersebut diperlukan keikutsertaan masyarakat dalam proses pembinaan diharapkan dapat membantu anak pidana untuk kembali seperti sedia kala. Namun sebagian dari masyarakat masih memberikan stigma buruk terhadap narapidana dalam hal ini anak pidana dalam lapas, sehingga pembinaan yang dilakukan terhadap anak selama di dalam lapas menjadi sia-sia dan bukan tidak mungkin mereka akan mengulangi perbuatannya yaitu melakukan pelanggaran terhadap hukum (Hartono, 2019). Oleh karena itu diperlukan kegiatan pembinaan sesuai minat dan bakat para Andikpas untuk menjadi bekal untuk menjalani kehidupan sekeluarnya dari LPKA. Apabila Andikpas mempunyai bekal keterampilan, maka masyarakat tidak lagi memandang sebelah mata.

Pembinaan Andikpas yang telah diatur sedemikian rupa dalam Peraturan PerundangUndang, nyatanya tidak mudah dilaksanakan oleh LPKA. Permasalahan utama pada LPKA dalam melaksanakan pembinaan adalah kurangnya Sumber Daya Manusia sehingga pembinaan Andikpas tidak dapat dilaksanakan secara maksimal. Selain itu kurangnya sarana prasara dan dana operasional menjadikan progam pembinaan terhadap anak menjadi terhambat. Untuk mengatasi permasalahan dan memperbaiki pelaksanaan progam pembinaan Andikpas, diperlukan penjalinan kerjasama kemitraan dengan kementrian, lembaga pemerintahan, lembaga sosial, atau perguruan tinggi.
Salah satu Tri Dharma Perguruan Tinggi yaitu pengabdian masyarakat dilaksanakan oleh Tim PKM-M Universitas Sebelas Maret dengan adresat LPKA Yogyakarta Klas II B. Kondisi dan permasalahan kurang maksimalnya pelaksanaan pembinaan keterampilan di LPKA Yogyarakarta ini menjadi fokus utama Tim PKM-M Universitas Sebelas Maret. LPKA yang bertempat di Jalan Mgr. Sugiyopranoto No. 35 Wonosari, Gunung Kidul ini merupakan gedung yang ramah anak dengan dilengkapi fasilitas seperti ruang rekreasi, ruang belajar, ruang olahraga, ruang kesehatan, perpustakaan dan tidak ada jeruji besi. LPKA Yogyakarta Klas II B mempunyai total kapasitas sembilan puluh orang yang hingga saat ini dihuni oleh sembilan Andikpas dengan jenis kelamin keseluruhannya laki-laki dan umur antara 15-19 tahun. Anak-anak yang masuk LPKA mayoritas karena terjerat kasus tawuran dan klitih yaitu suatu tindak kejahatan yang dilakukan seseorang untuk melukai atau menghilangkan nyawa seseorang tanpa adanya motif pelaku terhadap korban (Wawancara dengan Kepala LPKA Yogyakarta, 2020).

Selama Andikpas di LPKA, Andikpas akan mendapatkan pembinaan untuk membentuk pribadi yang lebih baik. Kegiatan pembinaan yang menonjol dan dominan di LPKA ini adalah pembinaan agama dan Sanggar Kegiatan Belajar (SKB) yang diberikan dalam rangka pemenuhan kebutuhan pendidikan formal Andikpas berupa program kejar paket oleh Dinas Pendidikan serta pembinaan moral dan agama yang bekerjasama dengan Kementrian Agama. Namun, dalam hal pembinaan keterampilan, pihak LPKA kurang berperan aktif dalam menyediakan pelatihan dan pembinaan keterampilan jika tidak didahului dengan inisiatif pihak luar atau dinas terkait. Padahal pendidikan dan pembinaan yang bersifat praktis dan applicable menjadi sebuah kebutuhan mendasar bagi Andikpas, hal itu dikarenakan Andikpas tidak mempunyai kesempatan untuk belajar langsung seperti kebanyakan anak didik pada umumnya (Manullang, 2013). Sebuah pendidikan aplikatif bagi Andikpas seharusnya merupakan pendidikan yang mempunyai karakter unik, meningkatkan life skills dan memberi bekal

Pendidikan 901 
untuk mandiri dalam hal ekonomi selepas Andikpas keluar dari LPKA (Maimun, 2015). Keterbatasan kegiatan pembinaan yang hanya berfokus pada pendidikan, menjadikan Andikpas sulit untuk menggali dan mengembangkan potensinya. Padahal tuntutan untuk bersaing di era Revolusi Industri 4.0 secara swadaya, merupakan hal yang tidak terelakkan bagi seseorang yang pernah melakukan tindak pidana, tidak terkecuali Andikpas. Hal ini disebabkan karena, adanya persyaratan kaku dalam beberapa proses seleksi pekerjaan yang menuntut calon pendaftarnya tidak boleh memiliki jejak pidana. Hal itu tentu akan menjadi penghambat besar bagi Andikpas untuk memperoleh pekerjaaan yang mereka inginkan, bahkan hampir dapat dipastikan seorang yang pernah dibina dalam LPKA ataupun lapas akan sangat sulit untuk mendapat pekerjaan (Yuniati dan Sutopo, 2019).Permasalahan pembinaan keterampilan yang belum dapat terlaksana dengan maksimal pada LPKA Yogyakarta Klas II B tersebut menjadi fokus utama tim PKM-Pengabdian Masyarakat Universitas Sebelas Maret.

Berdasarkan diskusi, para Andikpas menuturkan belum mempunyai gambaran atau tujuan hidup selepas dari LPKA. Namun seperti halnya anak pada umumnya, sejatinya seorang Andikpas juga memiliki potensi dalam dirinya. Para Andikpas menuturkan mayoritas memiliki ketertarikan, minat, dan keahlian dalam bidang seni rupa dan elektronika. Oleh karena itu, berangkat dari potensi dan minat tersebut, mendorong Tim PKM-M untuk menginisiasi program pelatihan pembuatan produk mini speaker dengan casing bambu yang diukir dengan motif batik yang selanjutnya oleh Tim dinamakan Bamboo Batik Speaker (Booster).

Booster adalah bentuk pemberdayaan Andikpas melalui pelatihan pembuatan produk speaker dengan casing bambu yang dihiasi motif batik. Tujuan pelatihan ini bertujuan untuk melakukan transfer pengetahuan sistem produksi yang sistematis. Progam ini menitikberatkan pada pembinaan untuk mengasah skills Andikpas dalam hal menciptakan produk yang bernilai jual tinggi sekaligus menumbuhkan jiwa entrepreneurship mereka guna bersaing di era Revolusi Industri
4.0. Sebagai sebuah pelatihan pembuatan produk, progam Booster dapat dikatakan sebagai sebuah pendidikan aplikatif yang cocok dan dibutuhkan para Andikpas. Pendidikan aplikatif tersebut bertujuan agar Andikpas dapat mengasah kreativitasnya untuk dapat dituangkan dalam industri kreatif.

\section{METODE PELAKSANAAN}

Metode yang digunakan pada pelaksanaan PKM Pengabdian Masyarakat ini adalah Participatory Rural Appraisal (PRA), yaitu suatu metode pendekatan dalam proses pemberdayaan dan peningkatan partisipasi masyarakat sasaran, yang menekankan pada keterlibatan masyarakat sasaran dalam keseluruhan kegiatan progam (Supriyatna, 2014). Pendekatan PRA dimaksudkan untuk menjadikan masyarakat sasaran (mitra) sebagai perencana, pelaksana progam, dan bukan sekedar menjadi objek progam. Oleh karenanya, pada progam Booster ini, Andikpas merupakan subjek progam dalam wujud masyarakat sasaran (mitra) PKM Pengabdian Masyarakat yang menjalankan keseluruhan rangkaian progam pembinaan terpadu yang dicanangkan.

Pelaksanaan pengabdian ini diawali dengan tahap persiapan yaitu dengan menetapkan sasaran mitra, kemudian koordinasi dan diskusi bersama mitra untuk mengetahui permasalahan mitra sehingga dapat bersama-sama dirumuskan solusi atas permasalahan mitra tersebut. Setelah itu Tim PKM-M mengurus administrasi perizinan guna memperoleh izin dari Kantor Wilayah Daerah Istimewa Yogyakarta Kementrian Hukum dan Hak Asasi Manusia untuk melakukan pengabdian di LPKA Yogyakarta. Tahap selanjutnya yaitu sosialisasi progam kepada Andikpas dan pihak LPKA Yogyakarta yang bertujuan untuk mengenalkan progam Booster sehingga mitra memahami bagaimana konsep dan teknis keberjalanan progam nantinya. Guna merealisasikan pelaksanaan progam Booster, Andikpas dibekali terlebih dahulu dengan materi-materi yang mendukung untuk membuat produk Booster. Penyampaian materi dikemas dalam bentuk Kelas Retro (Realisasi Elektro), 
Kelas Bantara (Batik Nusantara) serta Kelas Branding dan Marketing.

Tahap akhir pengabdian dilakukan dengan evaluasi. Tujuan evaluasi adalah untuk menentukan tingkat pencapaian atas sasaran yang ingin diraih dalam setiap progam kegiatan (Arikunto dan Jabar, 2019). Evaluasi dilakukan dengan pemberian kuisioner post test atas keberjalanan progam.

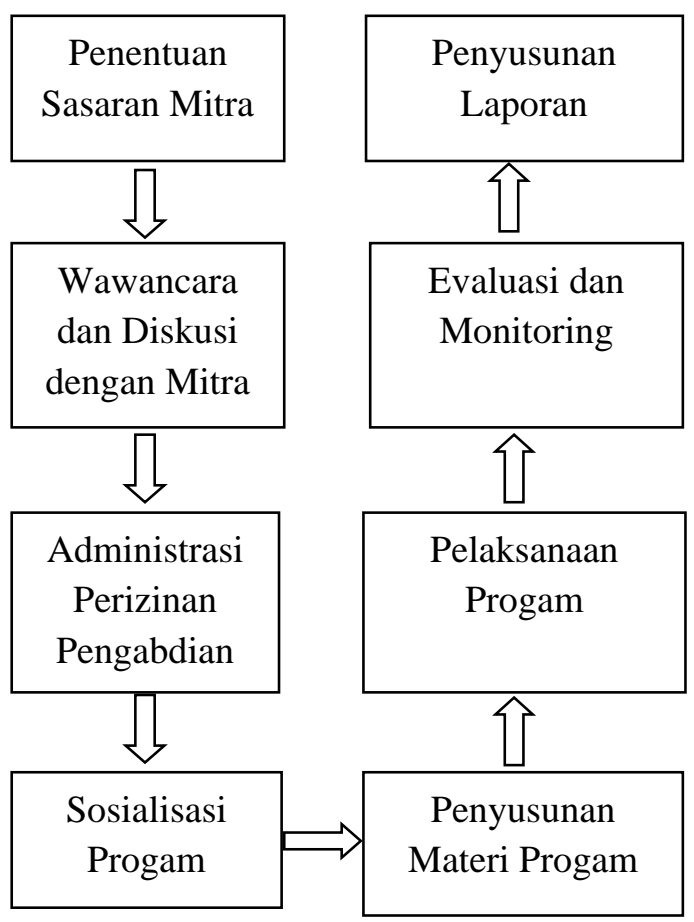

Gambar 1. Tahapan Pelaksanaan Pengabdian di LPKA Yogyakarta

\section{HASIL DAN PEMBAHASAN}

Sebagaimana telah dijelaskan sebelumnya bahwa LPKA Yogyakarta ditempati oleh sembilan Andikpas, namun hanya tujuh orang Andikpas yang mengikuti progam Booster karena dua Andikpas lainnya sedang menjalani proses isolasi sehingga tidak bisa mengikuti kegiatan progam Booster. Kegiatan PKM Pengabdian Masyarakat yang bertujuan untuk meningkatkan skills Andikpas secara keseluruhan berjalan secara kondusif dan lancar. Walaupun terdapat perubahan konsep dari yang awalnya akan dilakukan secara langsung (luring) berubah menjadi dilaksanakan secara daring (dalam jaringan) karena kondisi wabah Covid-19 yang belum mereda. Menyesuaikan dengan keadaan tersebut, mulai dari proses sosialisasi hingga pelaksanaan progam dilaksanakan secara daring (dalam jaringan) dengan memanfaatkan aplikasi google meeting.

Kegiatan pemberian materi di kelas dilakukan dalam kurun waktu dua minggu dengan total sebanyak lima kali pertemuan dengan masing-masing dua kali pertemuan untuk Kelas Retro dan Kelas Bantara serta satu kali pertemuan untuk Kelas Branding dan Marketing. Pada setiap kelas, materi disampaikan oleh orang yang kompeten di bidangnya. Dalam hal ini penulis Syaifullah Filard Latifan yang mempunyai latar belakang keilmuan teknik elektro bertugas memberi materi pada Kelas Retro. Erina Rahayu yang mempunyai basic keilmuan pada Seni Kriya Tekstil yang juga sebagai owner "Everyna Shock" bertanggung jawab memberi materi pada kelas Bantara dan Kelas Branding dan Marketing. Sebagai media untuk menyampaikan materi kepada Andikpas, pemateri memanfaatkan media power point dan pemutaran video guna mendukung dan memperjelas materi sehingga nantinya dapat ditangkap dengan jelas oleh Andikpas. Bilamana Andikpas kurang mengerti akan materi bisa menanyakan langsung kepada pemateri sehingga terjadi komunikasi dua arah. 


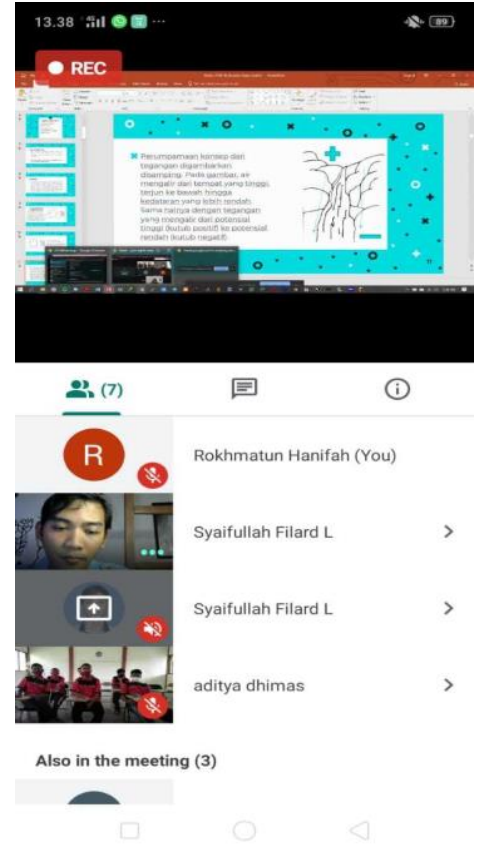

Gambar 2. Pemaparan Materi dalam Kelas

Kelas Retro merupakan kelas yang akan memberikan penjelasan mengenai elektro kepada Andikpas. Tujuan diadakannya kelas ini untuk memberikan pemahaman mengenai cara merakit komponen elektronika untuk menjadi sebuah speaker. Kelas Retro meliputi: 1) Pemahaman ilmu dasar elektronika dan rangkaian listrik; 2) Pengenalan alat dan bahan untuk merangkai multimedia speaker; 3) Pengenalan dan penjelasan fungsi komponen untuk membuat mini speaker; 4) Mendemonstrasikan cara merakit komponen yang baik dan benar; 5) Menguraikan permasalahan perakitan speaker dan perbaikannya.

Kelas Bantara merupakan tahap awal bagi Andikpas untuk mengenal batik lebih jauh, mengetahui seluk-beluk batik dan diharapkan semakin mencintai budaya nasional Indonesia. Kelas Bantara meliputi: 1) Pemberian materi seputar batik; 2) Pengenalan alat dan bahan untuk menggambar pola batik; 3) Menggambar pola batik; 4) Menggambar pola batik di media bambu.
Kelas Branding dan Marketing. Sebagai sebuah hilir dari suatu produksi komoditas, pemasaran merupakan hal vital untuk dilakukan. Pemasaran merupakan salah satu dari kegiatan pokok yang dilakukan untuk mempertahankan kelangsungan usaha, untuk berkembang, dan mendapatkan laba. Melalui kelas pemasaran Andikpas diberikan materi mulai dari materi dasar pemasaran, strategi pemasaran yang efektif, harga yang tepat, kemasan produk yang menarik, dan bagaimana memetakan pesaing. Mengikuti perkembangan zaman yang serba digital di era 4.0, Andikpas diajarkan cara pemasaran dengan media online. Banyak pilihan untuk melakukan pemasaran melalui media online, bisa dengan media sosial seperti facebook, instagram, whatsapp ataupun dengan dipasarkan di berbagai marketplace. Tidak hanya berfokus pada dimana nantinya produk akan dijual, hal yang tidak kalah penting untuk dibangun adalah branding. Salah satu hal yang memegang peranan penting dalam pemasaran adalah merek. Merek merupakan sesuatu yang dibeli oleh kosumen, memiliki nilai dan identitas atau ciri tertentu yang dilindungi secara hukum sehingga tidak dapat ditiru oleh pesaing. Merek mempengaruhi persepsi konsumen terhadap produk yang akan dibeli, sehingga terbentuk persaingan persepsi bukan produk (Tjiptono, 2011). Hal ini menunjukkan branding penting untuk dilakukan guna meningkatkan daya tarik masyarakat dalam membeli suatu produk. Pada kelas branding, Andikpas diajarkan cara-cara untuk membentuk suatu citra merek supaya dapat bertahan keunggulannya. 


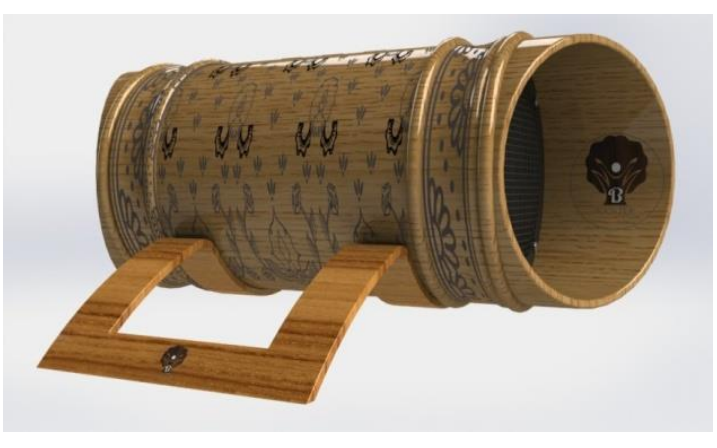

Gambar 3. Design Produk Booster

Konsep produk Booster yang menggabungkan karya cipta seni rupa murni dan terapan menjadikan Booster sebagai produk yang mempunyai keunikan dan nilai lebih dari pada produk speaker yang lainnya. Konsep seni yang dihadirkan Booster dengan mengangkat batik sebagai hiasan menambah nilai estetik dan nilai jual Booster. Selain itu, casing Booster yang berbahan bambu menjadikan Booster sebagai produk yang ecofriendly (ramah lingkungan). Ciri khas keunikan Booster menjadikannya memiliki daya pembeda yang dapat menjadi daya minat masyarakat terhadap produk Booster. Berbagai kelebihan dan keunikan yang dimiliki produk Booster diyakini memiliki peluang pasar yang besar dan mempunyai daya jual yang tinggi. Produk Booster diproyeksikan mampu terjual dalam kisaran harga Rp. 600.000,00 hingga Rp. 1.000.000,00. Dengan demikian produk Booster dapat mewujudkan income generating bagi Andikpas nantinya.

Pada akhir pelaksanaan progam Booster, seluruh Andikpas diberikan kuisioner yang berisikan evaluasi terhadap keberjalanan progam tersebut. Hasil evaluasi menunjukkan bahwa materi yang disampaikan dianggap baik oleh Andikpas (Tabel 1). Materi yang disampaikan menambah pengetahuan dan wawasan tentang ilmu elektronik dasar dan seni membatik untuk membuat produk speaker. Skor yang digunakan adalah 1 (Tidak Baik), 2 (Cukup Baik), dan 3 (Baik).
Tabel 1. Materi Progam

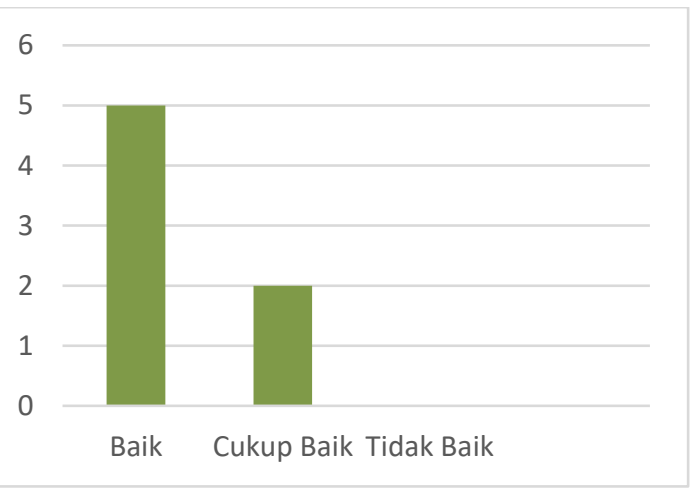

Andikpas menganggap pemateri memiliki penguasaan materi yang baik (Tabel 2). Pemateri dianggap menguasai materi sehingga materi yang disampaikan mudah untuk dipahami oleh Andikpas. Hanya saja karena kelas dilaksanakan secara daring terkadang terdapat gangguan sinyal yang menyebabkan penyampaian materi sedikit terganggu.

Tabel 2. Penguasaan Materi oleh Pemateri

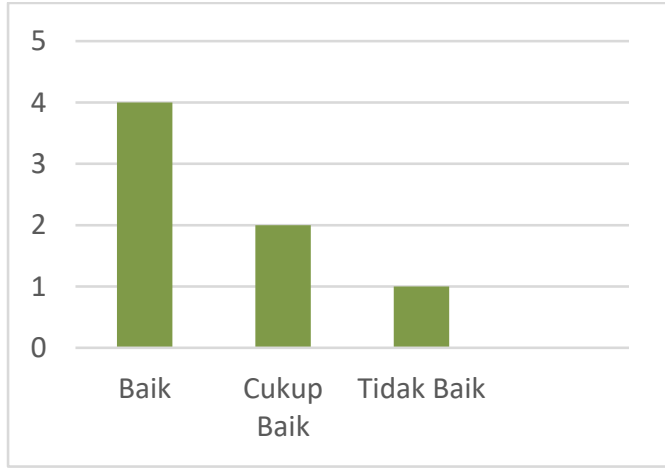

Andikpas menyatakan mendapatkan manfaat besar dengan adanya progam Booster (Tabel 3). Lebih lanjut Andikpas mendapatkan keterampilan baru tentang cara membuat produk yang memiliki aspek kreativitas tinggi dan nilai jual yang mahal berbahan dasar speaker dan bambu serta dengan sentuhan seni batik. Harapannya ke depan Andikpas dapat memunculkan ide-ide kreatif lainnya untuk mengembangkan produk Booster menjadi produk yang dikenal masyarakat luas dan mempunyai daya jual tinggi. 
Tabel 3. Manfaat Progam

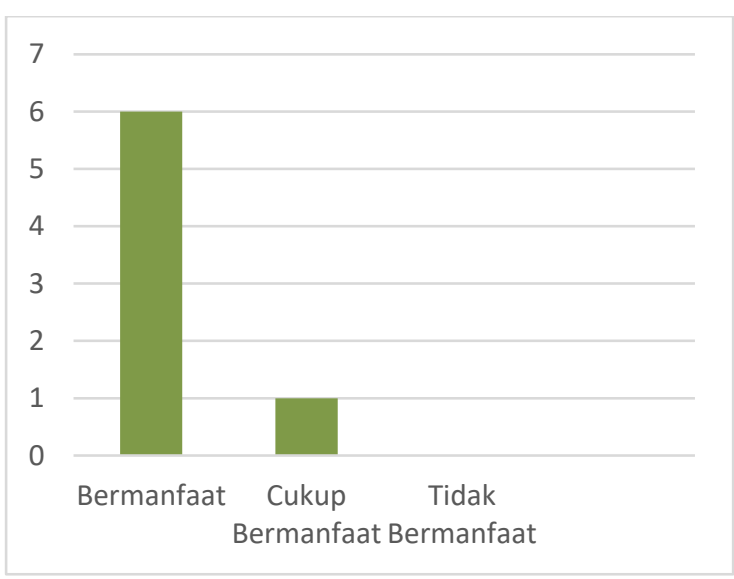

\section{KESIMPULAN}

Andikpas LPKA Yogyakarta sebagai mitra dari kegiatan PKM Pengabdian Masyarakat ini mendapatkan manfaat dan wawasan yang lebih luas kaitannya dengan kreativitas dalam membuat produk mini speaker casing bambu yang dikombinasikan dengan batik (Booster). Berbekal materi pelatihan yang telah disampaikan dalam kelas dan ketekunan Andikpas untuk terus berlatih dalam membuat produk Booster menjadi poin penting untuk nantinya dapat mengembangkan produk Booster yang lebih kreatif dan berdaya jual tinggi sehingga dapat memperluas pasar, baik di dalam negeri maupun di luar negeri.

\section{UCAPAN TERIMA KASIH}

Progam Pengabdian Kepada Masyarakat ini merupakan pelaksanaan kegiatan Progam Kreativitas Mahasiswa bidang Pengabdian Masyarakat (PKM-M). Para penulis mengucapkan terima kasih kepada Kementrian Pendidikan dan Kebudayaan atas pendanaan PKM-M 2020 tersebut, dan juga kepada Anak Didik Pemasyarakatan Lembaga Pembinaan Khusus Anak (LPKA) Yogyakarta Klas II B yang telah bersedia menjadi mitra kegiatan pengabdian masyarakat ini.

\section{REFERENSI}

Arikunto, et.al. (2009). Evaluasi Progam Pendidikan: Pedoman Teoretis bagi Mahasiswa dan Parktisi Pendidikan. Jakarta: Bumi Aksara
Gayatri, et.al. (2016). Negeri Harapan. Jakarta: Gramedia Pustaka Utama.

Hartono. (2019). Konsep Pembinaan Anak Dalam Lembaga Pembinaan Khusus Anak (LPKA) dalam Perspektif Hak Asasi Manusia. Alumni Magister Ilmu Hukum Universitas Mulawarman.

Maimun. (2015). Modal Pendidikan Efektif dan Aplikatif Menurut Abdullah bin Sa'ad Al-Falih. Tadris, 10 (2): 170-192.

Manullang, B. (2013). Grand Design Pendidikan Karakter Generasi Emas 2013. Jurnal Pendidikan Karekter, 3 (1) : 1-14.

Marlina. (2009). Peradilan Pidana Anak di Indonesia: Pengembangan Konsep Diversi dan Restorative Justice. Bandung: Refika Aditama.

Dewi, S., et.al. (2014). Kebermaknaan Hidup Pada Anak Pidana Di Bali. Jurnal Psikologi Udayana, 1 (2): 322-334.

Supriyatna, A. (2014). Relevansi Metode Participatory Rural Appraisal dalam Mendukung Implementasi UndangUndang Pemerintahan Desa. Jurnal Lingkar Widyaswara, 1 (1): 39-45.

Tjiptono, F. (2011). Manajemen dan Strategi Merek. Yogyakarta: Andi Offset.

Yuniati, I. S. \& Sutopo, O. R. (2019). Strategi dan Harapan Pemuda dalam Institusi Total. Jurnal Sosiologi Pendidikan Humanis, 4 (1): 21-29. 